\title{
Institutional aspects of Russia's transition to the sixth technological structure: political incentives, economic barriers and environmental impact
}

\author{
Svetlana Zenchenko ${ }^{1, *}$, Alexsey Zaytsev ${ }^{2}$, Anna Savtsova ${ }^{1}$, and Yana Radyukova $^{3}$ \\ ${ }^{1}$ North-Caucasus Federal University, 355017 Pushkina Street (Edifice 21), Stavropol, Russia \\ ${ }^{2}$ Orel State University named after by I.S. Turgenev, 302020 Naugorskoye Shosse, 40, Oryol, Russia \\ ${ }^{3}$ Derzhavin Tambov State University, 392000 Internatsional'naya Ulitsa, 33, Tambov, Russia
}

\begin{abstract}
The main subject of the World Economic Forum 2016 in Davos was the Fourth Industrial Revolution (Industry 4.0), characterized by, according to the chairman of the world economic fund Klaus Schwab, a combination of technologies that blur the boundaries between the physical, digital and biological spheres. Modern technologies are changing as fast as ever, creating new challenges and identifying promising opportunities for development. Our response to the challenges of Industry 4.0 is the neo-industrialization of the Russian economy, based on the use of modern industrial technologies and the development of human capital. However, the upcoming fourth industrial revolution is a serious challenge for the government. Unfortunately, most experts are not inclined to be optimistic about Russia's prospects in this race. The main competition of the new revolution is not that much about technologies themselves but about the skills and education that are necessary for their application. Competition is escalating at the level of education systems, but ready-made specialists in the context of globalization still need to be maintained, and so far, the low level of salaries in Russia only contributes to a further 'brain drain'. Finally, national characteristics and systematic approach are important in the Industry 4.0 development. The development of new industrial revolution elements is uneven, which is why the additional advantages of interdisciplinary research and development are missed out on. The task delivered by the President of Russia Vladimir Putin was to create a 'smart' economy, which determines the need for the rapid development of science and the dynamic implementation of its achievements. Since this task covers many aspects of life, a special integrating indicator is required to assess the success of its implementation. The concept of 'technological structure' is claiming its role today.
\end{abstract}

\section{Introduction}

\footnotetext{
*Corresponding author: zen_sveta@mail.ru
} 
A scientist-economist Nikolai Kondratyev coined the 'technological structure' concept. Studying the history of capitalism, he came up with the idea that the development of technology is wave-like [Kondratyev, 2002]. Kondratyev proved the existence of large economic cycles of 50-55 years long, which are characterized by a certain level of productive forces development (or 'technological structure'). Typically, such cycles end in crises similar to today, followed by the stage of transition of productive forces to a higher level of development. Ideas of Kondratiev N.D. on the allocation of interconnected technology complexes and the corresponding stages of technological development were further developed. From the point of view of Lvov D.S. and Glazyev S.Y. 'technological structure' is a system of interconnected industries (including dependent technological chains) with an equal technical level, which can be considered as a subsystem of a more general economic system [Lvov, Glazyev 1986].

Yakovets Y.V. defines the technological structure as 'a set of scientific and technical areas, interconnected by the resource and technological base, express ed in the core of the structure, the genotype of a certain stage in the development of the social technological basis' [Yakovets, 1996]. Therefore, the scientist assumes a different setup of the technological structure, including basic innovations that form qualitative features of the structure; production technologies that form the basis for material production restructuring; technologies of the economy non-productive area used in the service sector, in personal consumption and in military affairs. While comparing the approaches by Glazyev S. Y. and Yakovets Y.V., it should be noted that a clear definition of the technological structure concept made it possible to identify its basic elements, as well as to periodize the structures based on knowledge about the technical development of society. The 'technological structure' concept by Belousov V.I. is defined in a completely different way. Belousov A.V., understood it as 'a certain complex of applied basic and other innovations that provide a qualitative and quantitative leap in the social production forces development' [Belousov, 2010]. The disadvantage of this approach is that in this case only breakthrough innovations and completely new knowledge in science and technology are in the focus of attention. Klimova V.V. considers the technological structure in the form of 'a combination of certain technologies that are of the corresponding level of production development with a single technical level of productive forces and the general scientific potential' [Klimova, 2010]. Thus, the author takes as a basis for the structure not innovations, but technologies directly applied in production [1-12].

Haustov Y.I., Soloviev B.A. and Bocharov V.P. give the definition of the technological structure through relationships in their work. In their opinion, the technological structure is a 'system of production relations, which are a social form of functioning of a certain technological production mode that coexists with another system' [Khaustov, Soloviev, Bocharov, 2006]. A similar approach to understanding the technological structure is demonstrated by Akeliev E. He states that 'in any economic system, there are various socio-economic structure elements, that is, certain types of production relations with a specific management system, the organization of the economy subjects life (or business cells), forms of ownership of production means and the institutionalization of these management types'. [Akeliev, 2013]. The author also emphasizes that any technological structure is a 'self-reproducing system, that is, a form of socio-economic relations in which technology and scientific knowledge themselves directly participate in the creation of new knowledge and new institutions formation'. Close to the concept of technological structure is the concept of economic paradigm considered by Perez K. Such a paradigm refers to the most effective model at a given time, which arises based on the direct application of technologies in production and embodies new comprehensive criteria for the emergence of the most effective goods and 
services, processes, commercial firms and models of economic behavior [Perez, 2004]. Thus, there are several approaches to the definition of 'technological structure' concept: - Macroeconomic reproduction contour, which covers all stages of processing production factors and the corresponding type of non-productive consumption (i.e. an integrated complex of technologically related industries);

- The scope of technological knowledge;

- A type of economic relationship based on a specific form of ownership.

Each approach has its pros and cons, which leads to attempts to give a combined definition of technological structure. Seeing this, Sytnik A.A. explored the technological structure genesis and defined the technological structure as an integral complex of technologically related industries in conjunction with their adequate organizational and economic relations [Sytnik, 2011]. Thus, the technological structures are large groups of technological structures connected with each other by similar technological chains, within which a closed macroeconomic cycle is carried out, which includes all stages (such as production, processing and production of final products) that satisfy the public consumption type. In this case, the technological structure is assumed as the economy structure, which is a set of technological chains that determine the technological base of production.

Nowadays signs of the sixth and seventh technological structures are becoming more noticeable. The branches of the sixth technological structure include biotechnology, in particular cell biology; aerospace industry; nano technology; new materials; optoelectronics; artificial intelligence systems; microelectronics; photonics; microsystemic mechanics; information superhighways; software and simulation tools; molecular electronics and personnel management systems. The seventh technological structure relates to the creation of 'cold fusion' technologies, which radically change the terrestrial civilization energy potential.

The generation of technological innovations that determine the development of technological structure occurs within a complex of industries and indirectly by strong nonlinear feedbacks between them. This is a certain level of technologically related industries development, developing in many respects simultaneously.

A change in technological modes involves the development of a new way engineering and technology, which significantly changes the sectoral structure of the economy [Pavlova, 2017].

The country's economy elements transition to the sixth technological structure, are presented in table 1. [Schumpeter, 2008]

Table 1. Key aspects of the country's transition to the sixth technological order

\begin{tabular}{|c|c|}
\hline Area & \multicolumn{1}{|c|}{ Transition Components } \\
\hline Fundamental Science & $\begin{array}{l}\text { Many theories and concepts emergence that justify the laws of socio-economic } \\
\text { development amid a crisis in the scientific sphere at the state level. ypoвHe. }\end{array}$ \\
\cline { 2 - 2 } & A large number of technical and technological innovations emergence. \\
\cline { 2 - 2 } Economic system model & The synthesis of achievements in key technological areas. \\
\cline { 2 - 2 } & $\begin{array}{l}\text { The multi-layered nature of the economy, requiring significant technological } \\
\text { breakthroughs while maintaining the competitiveness of the economy. }\end{array}$ \\
\cline { 2 - 2 } & Innovations introduction (i.e. growth of key indicators). \\
\hline
\end{tabular}

We believe that the key areas in the transition to the sixth technological structure are science, as an independent sphere of social life (or fundamental science), and the economic system model. During the transition, the scientific sphere, shows a significant research intensification aimed at identifying the patterns of socio-economic development of both a country and an individual region, which, being an element of the new structure, 
simultaneously contribute to the crystallization of other elements inherent in the scientific field. In addition, technical and technological innovations, the introduction of which into production is gradually increasing, become an indispensable element of the new way of life, which leads to the synthesis of achievements in key technological areas. In the economic system model, a crisis or a cycle of crises are observed, which, in the coexistence of several technological structures, make a technological breakthrough, i.e. transition to a new way.

\section{Theoretical framework}

Institutional theory enters into the theoretical framework, according to which economic dynamics, including the change of technological patterns, are largely determined by the formal and informal rules that shape the economic behavior of individuals, both individual and cooperative. As a research methodology, the methods of economic comparative studies were used, including a comparative analysis of laws and regulations that, directly or indirectly, can affect the development processes of high-tech industries, including the formation of Industry 4.0 [12-15].

\section{Research results}

Today, the world is on the verge of the sixth technological structure. Its contours are just beginning to take shape in developed countries, primarily in the USA, Japan and China, and are characterized by focusing on the development and application of high-tech, or, as they say now, 'high technologies'. Everyone is accustomed to hearing bio- and nanotechnologies, genetic engineering, membrane and quantum technologies, photonics, micromechanics, thermonuclear energy, the synthesis of achievements in these areas should lead to the creation of, for example, a quantum computer, artificial intelligence and ultimately provide access to a fundamentally new level in the systems of government, society and economy.

The best way to overcome the crisis and protracted depression caused by the change of Kondratyev cycles, as noted by German economist Gerhard Mensch, is an innovative and technological breakthrough through the timely development and dissemination of basic technologies of the next, sixth way. Russia has a good chance to make this innovative technological breakthrough on the upward wave of the upcoming, sixth, Kondratiev cycle. To solve this problem, the country has high scientific and technical potential and enormous human resources, which must bring the innovative mechanism into action. Moreover, there is the strong political will.

In 25-30 years, according to the forecasts of specialists in the economies of developed countries, the sixth technological structure will become dominant. At the same time, a new scientific, technical and technological revolution will take place in 2020-2025, based on developments synthesizing the achievements of the above basic directions. There are reasons for such forecasts. In the USA, for example, the share of the productive forces of the fifth technological structure is $60 \%$, and the fourth is $20 \%$. In addition, about $5 \%$ is already in the sixth technological structure.

At the same time, Russia now faced the difficult task of moving to the sixth technological structure, having not fully mastered the fifth and fourth. The share of fifth-generation technologies in Russia is still about $10 \%$, and even then only in the most developed sectors like in the military-industrial complex and in the aerospace industry. More than $50 \%$ of the technology belongs to the fourth level, and almost a third to the third. This explains the complexity of the task facing domestic science and technology. A PwC survey in 2017 showed that, despite constant investments in technology, many companies in Russia cannot 
keep up with progress. Leaders of enterprises and large corporations note that earlier it was easier for them to keep up with innovations, because the main attention was paid to data analysis and search technologies. Now we are talking about information and communication technology and data security. The future is connected with the Internet of things and artificial intelligence. This was noted by $73 \%$ of respondents in the world (i.e. $65 \%$ in Russia).

Moreover, regarding the data of the Analytical report, 'Digital Economy Development Barriers in the Regions of the Russian Federation' [report dated 2019]; the lack of educational programs in the field of the digital economy is a key problem in most regions of Russia. The key barriers in the digitalization of the economy at the regional level include barriers in the field of legal regulation (17.3\%) and difficulties in financially securing the budgets of the region $(16.9 \%)$, the presence of administrative and managerial barriers (16.0\%), difficulties in the development of information infrastructure $(13.9 \%)$, the presence of information asymmetry $(11.1 \%)$ and barriers to the implementation of projects based on 'end-to-end' digital technologies $(6.0 \%)$.

Moreover, speaking about the level of innovations development, scientific and technological progress in Russia, it should be noted that with the established forms and methods of management, organization and financing of work, such a breakthrough will not be possible. We need drastic changes in these areas. In addition, they are possible only if science has the status of an independent branch of the economy with all the ensuing consequences. Leading countries of the world have already come to this. Most of them have a powerful scientific backlog, an active system of innovations that allows you to create and constantly maintain this backlog at a high level, quickly turning it into practical results.

However, analyzing the innovation activity indicators (table 2) in Russia, the number of personnel engaged in research and development is reduced (over the study period it decreased by 14.2 thousand people (or $2 \%$ )). The number of developed advanced technologies increases by an average of 111 units per year. The total cost of scientific research expenses in 2018 amounted to 56.16 billion rubles, which is 10 billion more than in the previous year, increasing over the period of the study (45 946.5 billion rubles in 2017). Thus, a decrease in the share of innovation-active enterprises is associated with an increase in the cost of innovation.

The infrastructure for the innovations development was created with substantial state support. However, no qualitative leap in their development and business activity has yet occurred, so there is still the potential for improving conditions. Four out of five institutes for the innovations development in Russia, function quite successfully, i.e. basic applied research funding or the Russian Science Foundation (RSF) and the Russian Foundation for Basic Research (RFBR); industrial parks, incubators and other institutions providing services to innovative companies like 'Skolkovo' and 'Mosgormash' the technology park and others; direct financing of innovative companies, for example, the Innovation Promotion Fund, 'VEB Innovations' and the priority areas financing for example, the Internet Initiatives Development Fund (IIDF). To a lesser extent, institutions have been developed in our country that purposefully develop cooperation between science and industry. Now these functions, as McKinsey analysts write, take over technology platforms, but industry leaders are not so often involved in them, which is necessary for an effective dialogue.

Table 2. Innovative activity key indicators in the Russian Federation from 2012 to 2018 (Source Federal State Statistics Service: http://www.gks.ru)

\begin{tabular}{|c|c|c|c|c|c|c|c|}
\hline Indicator & 2012 & 2013 & 2014 & 2015 & 2016 & 2017 & 2018 \\
\hline $\begin{array}{l}\text { The number of } \\
\text { staff engaged in } \\
\text { research and } \\
\text { development }\end{array}$ & 736.5 & 735.3 & 726.3 & 727 & 732.3 & 738.9 & 722.3 \\
\hline
\end{tabular}




\begin{tabular}{|l|l|l|l|l|l|l|l|}
\hline $\begin{array}{l}\text { (thousands, } \\
\text { people) }\end{array}$ & & & & & & & \\
\hline $\begin{array}{l}\text { The share of } \\
\text { domestic } \\
\text { expenses on } \\
\text { research and } \\
\text { development in } \\
\text { GDP, } \%\end{array}$ & 1.13 & 1.01 & 1.03 & 1.03 & 1.07 & 1.1 & 1.1 \\
\hline $\begin{array}{l}\text { The number of } \\
\text { advanced } \\
\text { manufacturing } \\
\text { technologies } \\
\text { developed }\end{array}$ & 864 & 1138 & 1323 & 1429 & 1409 & 1398 & 1534 \\
\hline $\begin{array}{l}\text { The volume of } \\
\text { innovative } \\
\text { goods and } \\
\text { services (billion, } \\
\text { rubles) }\end{array}$ & 1165.7 & 1847.4 & 2509.6 & 3072.5 & 3037.4 & 3258.3 & 3723.7 \\
\hline
\end{tabular}

The share of Russia in the patents global number is about $2 \%$, which is in the top 10 , but ten times behind the United States (25\%) and twice as much as the United Kingdom (4\%) [16]. Financing remains the weak point of the Russian innovation system, given that companies with state participation represent a significant part of the business sector. In terms of business sector contribution to research and development, Russia is comparable to Chile $(32.8 \%)$, Greece $(31.4 \%)$, and Slovakia $(25.1 \%)$. Russian indicators are two or 2.5 times lower than most developed and fast-growing economies like China (74.7\%), USA $(64.2 \%)$, Germany $(65.6 \%)$, France $(55.7 \%)$, where business funds are the main source of funding for research and development [The Global Innovation Index, 2019].

In addition, analyzing the results presented in the Report on the Global Innovation Index 2019, which assesses the countries positions in terms of the their innovation effectiveness and technology, as well as detailed information on individual indicators by which such effectiveness is assessed, Russia's results are extremely weak.

According to the McKinsey Global Institute, in order to ensure an annual GDP growth of 5.5 to $6.5 \%$ in the current decade, Russia should generate a 2 to $3 \%$ increase through innovation. If this succeeds, then innovation will increase GDP by 2025 by 3 to 5 trillion dollars, and Russia from the 'innovation sponge', which absorbs and assimilates existing knowledge and technologies, can turn into a global innovation leader. However, today the situation in the innovation sphere is far from favorable.

Today, the leaders in the field of innovation and export of high-tech products are China, Germany and the United States. In 2018, China, but with the exports volume of high-tech products, finally broke away from everyone and, in the future, by 2020 will only strengthen its leading position. At the same time, the share of high-tech products in the export of manufacturing industries of the People's Republic of China is $30.0 \%$, being second only to Singapore, which is $-47.0 \%$.

Table 3. High-tech exports of the leading world countries in the years of $2003-2017$ / billion dollars.

\begin{tabular}{|c|c|c|c|c|c|}
\hline$\#$ & Country & 2003 & 2006 & 2010 & 2017 \\
\hline 1 & China & 108,6 & 273,1 & 406,1 & 560,0 \\
\hline 2 & Germany & 106.2 & 163,2 & 158,5 & 193,1 \\
\hline 3 & the USA & 160.3 & 219,0 & 132,4 & 147,8 \\
\hline 4 & Singapore & 76.4 & 124.7 & 127,0 & 135,6 \\
\hline 5 & The Republic of Korea & 57,5 & 93,3 & 121,5 & 121,3 \\
\hline
\end{tabular}




\begin{tabular}{|c|c|c|c|c|c|}
\hline 6 & France & 57,0 & 81,5 & 99,7 & 113,0 \\
\hline 7 & Japan & 107,0 & 129.2 & 122,0 & 105,1 \\
\hline 8 & Netherlands & 50,2 & 69.5 & 59,5 & 69,0 \\
\hline 9 & Switzerland & 23,2 & 31,2 & 42,8 & 53,4 \\
\hline 10 & India & 2,7 & 4,9 & 10,1 & 17,0 \\
\hline 11 & Russia & 5,5 & 3,9 & 5.1 & 8,7 \\
\hline 12 & Brazil & 4.5 & 8,4 & 8.1 & 8.4 \\
\hline
\end{tabular}

According to the Nature journal, Russia took 13th place in the world as a supplier of highquality scientific publications in major journals. Moreover, out of the 10 leading countries only China showed double-digit growth. The Japan Agency for Science and Technology determined that China came out on top in the world in the number of $10 \%$ of the most cited works in the following four sectors, i.e. computer science, mathematics, materials science, engineering, and the second after the USA in physics, environmental biomedicine, and clinical medicine. An analysis of the scientific publications of Chinese scientists shows that China, by most indicators, is rapidly catching up with the United States and Russia back in 1997.

Table 4. Country rating of scientific publications 1996-2017

\begin{tabular}{|c|c|c|c|c|c|c|}
\hline Place & Country & Papers & Cited Papers & $\begin{array}{c}\text { Number of } \\
\text { citations }\end{array}$ & Citation index & h-index \\
\hline 1 & The USA & $\begin{array}{c}10193 \\
964\end{array}$ & 9165271 & 240363880 & 23,58 & 1965 \\
\hline 2 & China & 4595249 & 1525851 & 32913858 & 7,16 & 655 \\
\hline 13 & Russia & 860847 & 842674 & 5947119 & 6,91 & 467 \\
\hline 64 & Belarus & 33408 & 44221 & 148685 & 7,38 & 146 \\
\hline
\end{tabular}

The concept of the fourth industrial revolution is associated with the German program Industry 4.0, in which large German business concerns, with the support of the Federal Government, create fully automated production facilities, lines and products, interacting with each other and consumers within the framework of the Internet of things concept. The Industry 4.0 'key driving force' is the increased integration of 'cyber physical systems', or CPS, into production processes. This is the production part of the Internet of things, which is rapidly penetrating our lives. The fourth industrial revolution will also affect the distribution of roles between countries. Where will the place of Russia be? According to Aleksey Komissarov, Director General of the Industrial Development Fund. Russia has lagged behind lately in terms of technological development, and only some areas has narrowed the gap in recent years. Perhaps a new industrial revolution will give Russia a chance.

Pospelova T.V. and Kornev D.A. name a whole range of obstacles to the Industry 4.0 development in Russia [Pospelova, Kornev 2017]. Among the factors identified by them, special attention is paid to the problem of state scientific policy. Do not forget that for many areas of research and development, it is the state that is the key investor because of the inability to get quick returns. Even the state program to support and develop biotechnologies until 2020 is more focused on supporting pharmacology, rather than creating new materials and other interdisciplinary research. In the future, this may become a reason for Russia's serious biotechnological lag behind industry leaders.

The problem of Russia's entry into the fourth industrial revolution is that it is still too new for it, and, as Finpro's Advanced Production in Russia study confirms, Russia does not have Industry 4.0 as a phenomenon that combines advanced developments into a single system. 
Although its individual elements are used. These include robotics, 3D printing and Big Data. Since 2015, there has been a National Industrial Internet Consortium. Members of the association have access to best practices, risks are shared among participants, due to which they get the opportunity to increase competitiveness, participate in the formation of requirements and standards, as well as develop a common position on the regulatory framework for the industry. Glazkov B. a Director of 'Rostelecom' the Center for Strategic Innovations believes that the Global Navigation Satellite System (or GLONASS) system, once criticized by many, can be very popular in the new conditions. Well-developed production automation systems in the mining and nuclear industries.

According to the joint reports of the National Research University Higher School of Economics and the World Bank [World Bank Report 2015], in Russia with a formally high level of education, there is an urgent lack of social and behavioral skills (for example, the ability to work with people), as well as cognitive skills of high order (or 'problem solving skills'). Let us compare these data with the results of the 'Foresight of Competencies 2030' study conducted by experts from 'SKOLKOVO' the Moscow School of Management, the Agency for Strategic Initiatives, Re-engineering Futures and the 'Practice Community Designers' company. In the 'Atlas of New Professions' the so-called over-professional skills are highlighted and they will be in need in the future. Among them are multilingualism, understanding of intersectoral communication, and the ability to work in conditions of high uncertainty, creative skills and the ability to work both with teams and with individuals. According to World Bank surveys, it is behavioral skills that are currently lacking, and the question of creative abilities is traditionally controversial. The authors of Atlas believe that with the development of automation everyone will have to develop them, since it is the ability for creativity and non-standard thinking that distinguishes a person from machines.

It is known that the education system is changing quite slowly, and because technologies are changing so rapidly, it may even seem almost static. As a result, more and more countries are moving to lifelong learning. This is especially noticeable in Europe, where an aging population and an increase in retirement age have led to the spread of retraining. Apparently, this trend will sharply increase in the coming years due to the high degree of production automation, on which the fourth industrial revolution is based.

The foreign experience supports the opinion that the development of science should move into the walls of universities. Is it possible? Not to mention the fact that the main task of universities is to train specialists. It is difficult to imagine an educational institution that can contain and efficiently operate powerful experimental research stands and technological complexes.

It is equally erroneous to believe that innovative development can only be ensured by scientific organizations that are owned or financed by private corporations, whose main interests and goals, as known, in many cases do not coincide with the goals and interests of the state.

Large non-state corporations are certainly involved in the creation of new knowledge. However, this process is strictly limited by their desire to ensure the competitiveness of their products. Moreover, corporations are very reluctant to take risks when financing research. Moreover, in the presence of a monopoly position in the market, sometimes they even freeze the process of acquiring new knowledge.

I believe that in our situation, the innovation process must be made mandatory for everyone, and first of all for large corporations. For this, in particular, it is worth returning to the practice of allocating $2 \%$ of profits to the Technological Development Fund. In this way, you can create the conditions for the transition of the economy into the sixth technological structure. However, we must not lose sight of the fact that there are a number of important tasks in the field of science and technology, their solution is the direct responsibility of the state. It falls within the scope of its responsibility. This means that the state must have its 
own scientific institutions capable of solving these main national problems of innovative development.

The effectiveness of the state 'scientific' policy primarily depends on the availability of a systemic regulatory framework. Unfortunately, in our country such a base is practically absent. Gaps in the regulatory framework interfere with the normal interaction of academic, sectoral and university science [16-27].

In the USA, the National Science Foundation plays the role of the innovation center. The Office of Science and Technology under the President of the United States manage it; in France, it is the National Center for Scientific Research of the Inter-Ministerial Committee for Scientific and Technological Research under the President of the French Republic.

\section{Discussion and interpretation of the results obtained}

In our opinion, an important link in the proposed innovation system in Russia should be research and technological development centers based on the Russian Academy of Sciences and state research centers with the universities involved and capable of providing scientific, methodological and educational activities.

These research and technological development centers should be established not only in the five priority areas of technological breakthrough, designated by the president, but also in such an important area as materials science and materials production. After all, it is the materials that are the base that all scientific and technological achievements are built.

The innovation process is a kind of continuous conveyor of the new knowledge generation and its use for the production of high-tech products, including fundamental, exploratory and applied research, technology development, the creation and industrial production of hightech products. Including venture capital attraction based on public-private partnership.

Unfortunately, over the past twenty years, the relations between state scientific organizations of different sectors (i.e. academic, university and industry) have weakened greatly. The same can be said about the links between research and production structures. This not only 'impoverishes' each of the parties, but also significantly inhibits the implementation of innovative developments. Meanwhile, in domestic practice, there are examples of effective cooperation between academic, industry and university organizations, which led to the creation, in particular, of new materials and technologies. This form of cooperation should grow and deepen. Interaction can be realized on a long-term basis within the framework of structures uniting representatives of academic, industry, industrial organizations, and businesses working in certain segments of production and market.

One of the most important tasks of structural transformations in the research and development sector is to increase the level of communication and cooperation of various organizations. The network development relationships between institutes and individual research teams will contribute to the intensification of information exchange, increase research efficiency and increase the mobility of scientific personnel. It is extremely important to build such a network of relationships and cooperation between organizations of basic and applied science, between universities and research institutes and laboratories, between research structures and enterprises. The most important tool to stimulate such interaction is to expand the existing experience of special competitions for conducting integrated research and project implementation. In addition, in order to increase the transparency of research organizations activities and stimulate scientific cooperation, a standard of corporate reporting for scientific organizations and universities will be introduced. The existing practice of supporting basic and applied research in higher education institutions and the integration of scientific and educational activities will also expand. To this end, priority financing will be provided for research and innovation infrastructure of research and federal universities, Moscow State University and St. Petersburg State University, other leading Russian 
universities, as well as the creation of basic departments of universities at RAS institutions and national research centers, and state research centers, while ensuring student participation base departments in the research process. The low capital-labor ratio of research is no less, and in many branches of science, perhaps a more important reason for low productivity than even the quality of personnel.

Table 5. Target indicators for the task implementation

\begin{tabular}{|l|l|l|l|}
\hline \multicolumn{1}{|c|}{ Indicator Name } & \multicolumn{1}{|c|}{2010} & 2016 & \multicolumn{1}{|c|}{2020} \\
\hline $\begin{array}{l}\text { Russia's share in the publications global } \\
\text { number, \% of the publications total number in } \\
\text { top-rated journals. }\end{array}$ & 2,48 & 4 & 5 \\
\hline $\begin{array}{l}\text { Specific equipment (cost of equipment), of } \\
\text { one researcher/ thousands of rubles. }\end{array}$ & 860 & 1500 & 3000 \\
\hline
\end{tabular}

The state economy transition to a new mode is a long and multifaceted process and carries many associated risks. Given these circumstances, Russia's entry into the sixth technological structure is not an end in itself, but a matter of developing the economy, ensuring the country's security and international status, and achieving a high level of human well-being.

Traditionally, the problem of transition to Industry 4.0 and the sixth technological structure is considered as an economic project. The tasks of increasing production efficiency, GDP growth and tax revenues, improving the quality of life, are goals of an economic nature. The leader in the development of Industry 4.0 is Germany, where the Silicon Valley analogue of Intelligent Technical Systems OstWestfalenLippe is created. Similar programs have been launched in the Netherlands, France, Great Britain, Italy, Belgium, etc. In the United States since 2012, there has been a non-profit 'Coalition of leaders in smart manufacturing' combining business, universities and government agencies; the 'Chinese manufacturing $2025^{\prime}$ doctrine has been adopted in China and the task has been set to consistently bring level of their industry from 2.0 to 3.0 and then also breaking through to 4.0; the Japanese are actively discussing their own concepts of 'Connected Factories' (or Monodzukuri). At the same time, the transition to Industry 4.0 will lead to a fundamental change in the employment structure, hundreds of thousands of specialists may be left without work, and countries implementing the fourth industrial revolution will need to be employed to avoid a social explosion. Therefore, the advanced digitalization and informatization underlying Industry 4.0 goes far beyond the manufacturing sector, affecting the underlying social processes. The political background of the digital economy development is rarely considered; however, the problems of forming a sixth technological mode exist. For example, [Krutakov L., 2017] notes that the negotiations on the Trans-Pacific Trade and Transatlantic Trade and Investment Partnerships (TTP / TTIP) have finally dispelled the illusion of building an apolitical common market as a measure of functioning rationality. 'In 2014, General Electric, AT\&T, Cisco, IBM, and Intel created the Industrial Internet Consortium / IIC'. Among the objectives of the IIC is the development of common information standards for the digital economy, as well as the financial architecture and asset management system. The combination of information and financial infrastructure in a single legal and power circuit (TTIP / TTP / NATO) creates a new pole of political power, formed not through access to resources, as it was in the industrial period, not through access to technology, as it happens in the postindustrial period, but through access to infrastructure. In this case, the infrastructure should be considered as a whole chain of elements like hardware solutions, software and a system of institutions (or laws).

In this situation, through the prism of potential competitive advantages formation in Industry 4.0, legislative acts should be considered, which are currently being analyzed, purely as political ones. For example, [Federal Law of 05/01/2019 \#90-Federal Law], which was assigned as the 'Sovereign Internet Law'. Some analysts [Tishina Y., 2019] are of the opinion 
that the implementation of this law 'may slow down the development of the Internet of Things in Russia, which is sensitive to potential data transmission delays'. Obviously, such laws should be considered not only from the political and military point of view, but also from the technological point of view, namely, what risks and prospects the introduction of similar normative acts carries the Industry 4.0 development and the transition to the sixth technological structure.

As an example of the economic and institutional analysis of Industry 4.0, which becomes a guide to the social understanding of current economic processes, [Industry Challenges 4.0, 2018] 'The Action Plan adopted at the IndustriALL Global Union World Conference' Industry 4.0: 'Implications for Trade Unions and Sustainable Industrial Policy', October 26 and 27, 2017, in Geneva, Switzerland, where it is proposed to 'formulate and implement a coherent and extensive program' of the 'Fair Transition' (i.e. meaning Industry 4.0) for inclusion in any negotiations with governments and companies'.

\section{Conclusion}

Thus, it seems appropriate to conduct monitoring and analysis of the institutional environment from the standpoint of seeking competitive advantages within the framework of Industry 4.0, the Internet of Things, biotechnologies and other poorly defined, but technologically promising niches for the development of science and production. The results of such an analysis (by the scientific community, public organizations or state structures) could become both a guideline for socio-economic dynamics and a criterion for an objective assessment of the current political process.

The modern world is changing, and, of course, those countries that actively invest in the development of high technologies will have a global competitive advantage. Russia currently has a need for a transition to an innovative way of development. We will not be able to withstand competition and achieve a strong position in the world arena without properly developing science and high technologies, as well as testing the achieved scientific results in business, production, and the social sphere. In addition, another important issue that needs to be addressed at the state level is the achievement of a reasonable 'social' balance between a technological breakthrough and the state intervention degree in market mechanisms.

Thus, the transition of Russia to the sixth technological structure is mixed. Today, excluding the defense complex, in most high-tech industries, Russia is still globally uncompetitive. Science and technology in Russia are developing in accordance with special national and mega projects, strategic programs, which may include special mega projects. The mechanisms of state support for long-term basic and applied research cover the following areas, i.e. national defense, basic sciences, space technology, energy, natural resources and environmental protection, agriculture, transport, local and regional development. The main abilities for the science self-development can be determined as:

1. The state ability for scientific innovation;

2. The state ability for technical innovation;

3. The state ability to use new technologies;

4. The state ability to use global information;

5. The state ability to invest in scientific research.

Research organization improvement is carried out in Russia in the following areas:

- Along with the scientific institutions reduction, new ones have been created to carry out work in the most promising areas;

- A number of research institutes have been transformed into commercial companies, which should guarantee the introduction of research results into production;

- State Key Laboratories have been established where advanced basic research is being 
conducted;

- The programs of leading universities require their transformation into high-level research universities with a developed material and technical base, the best teaching staff, and a reduced number of students per teacher;

- In order to increase the efficiency of scientific institutions functioning, all departments have been transferred to the contract hiring system.

The successful foreign experience application and the completion of the transition to the appropriate model for organizing scientific research will allow Russia to create a powerful material base for science, ensure high efficiency of Research and Development in the future and achieve commercial results from their practical application.

Continuous socio-economic growth in Russia places ever-higher demands on basic research, as many scientific and technical problems require solutions based on comprehensive research in the most advanced fields of science. Russia considers increasing the potential of basic research as a strategic base for science and technology development, creates experimental bases, and equips research institutes with the most advanced experimental laboratory equipment.

To sum up, the fourth industrial revolution and the sixth technological structure will have a serious impact on the labor market structure, education and society. Therefore, despite the fact that experts are sounding the alarm about the threat of mass unemployment, developed countries do not hinder the development of technology. The United States takes a position bordering on connivance, and the European Union, known for its preventive measures, so far is limited only to recommendations and calls to prepare a social ecosystem for technological innovations. Today Russia is at a disadvantage due to the lack of a systematic approach to Industry 4.0; also, losing the main advantage of the new revolution, i.e. the multidisciplinary focus. Chinese experience is the one to be looked at as an example. China stimulates advanced training, attracts the best lecturers to its universities and does not seek to 'defeat' automation, but seeks to be the first to implement it in order to maintain its position. Russia should revise educational policies and reform the labor market in order to get more fair salaries from employers. Otherwise, Russia risks becoming just a supplier of labor resources for more technologically successful countries, as it previously became a supplier of natural minerals.

\section{References}

1. E.S. Akeliev, Modern Trends in the Development of the Industrial and Technological Structure in the Knowledge-Based Economy Paper presented at the XII International Scientific and Practical Conference of students, graduate students and young scientists. 426-428 (Tomsk, 2013)

2. http://ac.gov.ru/files/publication/a/25838.pdf (Last accessed 21.03.2021)

3. http://www.perspektivy.info/print.php?ID=47065 (Last accessed 24.03.2021)

4. Y. M. Berger, Scientific and technological component of the total national power of China. Problems of the Far East, 6, 4-23 (2016)

5. A. A. Bykov, Technological structures and the spatial component of economic development. Belarusian Economic J. 1, 114-126 (2014)

6. http://documents.worldbank.org/curated/en/460821468107067600/Developing-skillsfor-innovative-growth-in-the-Russian-Federation. (Last accessed 11.03.2021)

7. http://www.consultant.ru/document/cons_doc_LAW_323815/ (Last accessed 26.03.2021)

8. http://www.gks.ru (Last accessed 26.03.2021) 
9. A. V. Fomina, Kondratiev's Cycles in the Russian Economy (Moscow. International Fund of N. D. Kondratyev, 2015)

10. http://www.industriallunion.org/sites/default/files/uploads/documents/2017/SWITZERLAND/Industry4point 0Conf/industry_4_rus.pdf (Last accessed 27.03.2021)

11. Yu. I. Khaustov, Innovation process in the system of public relations. Voronezh. Publishing house of the Voronezh state University (2006)

12. V. V. Klimova, Technological structures - the material basis of the economic development of society, Bulletin of SamGUPS, 2(20), 30-32 (2010)

13. N. D. Kondratiev, Big cycles of conjuncture and theory of foresight: selected works (Moscow, Russia: Economy, 2002)

14. L. Krutakov, World order 4.0 is in danger. Sanctions and cancellation of 'big future' (2017) https://www.nalin.ru/mirovoj-poryadok-4-0-v-opasnosti-sankcii-i-otmenabigdatogo-budushhego-5845 (Last accessed 28.03.2021)

15. D. S. Lvov, S. Y. Glazyev, Theoretical and applied aspects of NTP management. Economics and mathematical methods, 5 (1986)

16. http://www.slideshare.net/morellimarc/mckinsey-china-effect-on-global- innovation2015. (Last accessed 28.03.2021)

17. http://www.itu.int/en/ITU-D/Statistics/Pages/publications/mis2015. Aspx (Last accessed 30.03.2021)

18. V. V. Pavlov, The effect of the sixth technological order on the Russian labor market. Paper presented at the X International scientific-practical conference "Economic growth of the Republic of Belarus". Minsk, May 19-20, 43-45 (2017)

19. C. Perez, Finance and technical change (Cheltenham, 2004)

20. T. V. Pospelova, D. A. Kornev, Industry 4.0: is there a place for Russia? (2016) https://snob.ru/profile/28549/blog/109523. (Last accessed 30.03.2021)

21. J. Schumpeter, Theory of Economic Development. Moscow. Directmedia Publishing (2008)

22. A. A. Sytnik, Modern approaches to the definition of technological structures. Bulletin of the Saratov State Socio-Economic Institute, 3(37), 41-43 (2011)

23. A. A. Sytnik, The genesis of technological mode. Bulletin of the Saratov State Technical University, 1(52), 245-248 (2011)

24. The Global Innovation Index 2019 Cornell University, INSEAD, World Intellectual Property Organization (2019).

25. Y. Tishina, Operators thought about that the real Sovereign Runet might be too slow for IoT (2019) https://www.kommersant.ru/doc/3917500 (Last accessed 30.03.2021)

26. A. A. Urasova, Key aspects of the transition of the economic system to the sixth technological mode. Ars Administrandi. The art of management, 1, 52-61 (2017)

27. M. A. Yudina, Industry 4.0: prospects and challenges for society. Public administration. Electronic bulletin, $\quad 60, \quad 197-215 \quad$ (2017) http:/ejournal.spa.msu.ru/vestnik/item/60_2017yudina.htm. (Last accessed 30.03.2021) 